\title{
Evaluate Technical Standards of Implemented Soil Bund in Central Rift Valley of Ethiopia: The Case of Adama, Lume and Dodota Districts
}

\section{Kalkidan Fikirie ${ }^{1 \rtimes}$ \\ Abebe Bezu ${ }^{2}$ \\ Melat Eshetu ${ }^{3}$ \\ Daniel Bekele ${ }^{4}$ \\ Mohamed Rabos}

'Holeta Agricultural Research Center, Holeta, Ethiopia. 'Email:kalkidanfikire@gmail.com Tel:+251912758580

${ }_{2,3,4,5}$ Melkassa Agricultural Research Center, Melkassa, Ethiopia.

'Email:abebe.bezu@yahoo.com Tel: +251911048796

Email: melateshe4@omail.com Tel:251920698213

'Email:tdanielbekele@gmail.com Tel:+251913366086

${ }^{5}$ Email:mohammedrabo3@gmail.com Tel:+251926176837

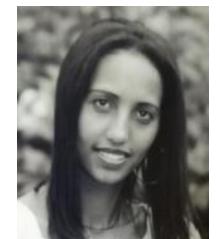

Corresponding Author

\begin{abstract}
Land degradation in the form of soil erosion is a serious problem in Ethiopia. To combat this, the government undertaken SWC measures across the country since 1970's. This study therefore, investigated technical standard of implemented soil bund practice in CRV of Ethiopia. A mixed methods approach was employed, combining qualitative and quantitative data collection tools; $\mathrm{HH}$ survey, KI interviews, FGD, observation and desk literature review. HHs were randomly chosen from the sampling frame exist at PA level and a total of $150 \mathrm{HHs}$ were selected for this study. Further, soil bund structures were measured and evaluated. The data analysis was carried out by using descriptive statistics, one way ANOVA and chi-square tests. Results of the study showed that soil bund parameters implemented under the standard are bund spacing, width and height of embankment. While bund top width, bottom width, berm width and top width of embankment were better. Soil and stone bunds are mostly preferred, whereas check dam is the least preferred technology to implement in the study area. Major challenges farmers faced during SWC practices implementation, shortage of labor, lack of technical skills, fear for animal trampling, lack of awareness and lack of sufficient farm tools. Hence, the study has concluded that every year SWC practices implemented by community mobilization are not standardized and consequently it is difficult to manage the watershed in different areas. Therefore, the study suggests that well organized training should be given for experts at different levels to fill the technical gap on their skills and extension services like demonstration should be held for all stakeholders before implementing the SWC structures.
\end{abstract}

Keywords: Farmers' perception, Land degradation, Soil erosion, Technical standard.

Citation | Kalkidan Fikirie; Abebe Bezu; Melat Eshetu; Daniel Bekele; Mohamed Rabo (2020). Evaluate Technical Standards of Implemented Soil Bund in Central Rift Valley of Ethiopia: The Case of Adama, Lume and Dodota Districts. Agriculture and Food Sciences Research, 7(1): 51-57.

History:

Received: 17 January 2020

Revised: 21 February 2020

Revised: 21 February 2020

Accepted: 26 March 2020

Licensed: This work is licensed under a Creative Commons Attribution 3.0 License (oc) E E

Publisher: Asian Online Journal Publishing Group
Acknowledgement: All authors like to thank government officials of Adama, Lume and Dodota districts, development agents for their support during data collection phase of the study. Special thanks go to Adama, Lume and Dodota districts' natural resource coordinators for their guidance and provision of detailed information about the soil and water conservation practices in the study area.

Funding: Authors would like to thank Ethiopian Institute of Agricultural Research (EIAR)/ Melkassa Agricultural Research centre (MARC) for the financial support to us to pursue this research.

Competing Interests: The authors declare that they have no conflict of interests.

Transparency: The authors confirm that the manuscript is an honest, accurate, and transparent account of the study was reported; that no vital features of the study have been omitted; and that any discrepancies from the study as planned have been explained.

Ethical: This study follows all ethical practices during writing.

\section{Contents}

1. Introduction

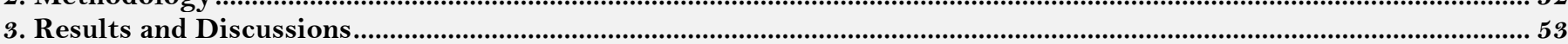

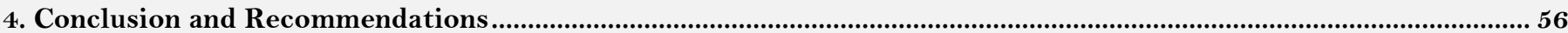

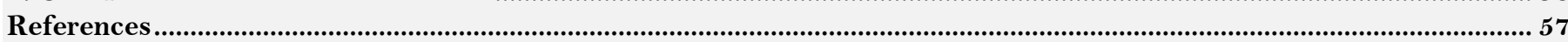




\section{Contribution of this paper to the literature}

This study contributes to existing literature by investigating technical standard of implemented soil bund practice in CRV of Ethiopia.

\section{Introduction}

\subsection{Background and Justification}

Land degradation in the form of soil erosion is a serious problem in Ethiopia. Most productive land has been exposed to degradation and threat both economic and survival of the people [1]. Soil erosion is a cause of land degradation that affects the soil physical, chemical and biological properties, results in onsite soil nutrient loss, soil structure and texture damage and offsite water pollution, flooding and sedimentation of water resources in the country [2].

In Ethiopia, alarming rate population increment, continuous and steep slope farming, low vegetation cover, deforestation and insufficient soil and water conservation practices cause annual soil loss of about 1.5billion metric tons and resulted, $1.2 \mathrm{ton} / \mathrm{ha} / \mathrm{yr}$ cereal yield reduction on average [3, 4]. In addition, the continually increasing land use change is exasperating the rates of soil erosion, soil fertility reduction, crop yield decline and food insecurity [5, 6].

Continuous soil erosion threatens communities' livelihoods especially in drought prone areas, where arable land is a scarce resource in the country. According to Belay, et al. [7] report, deforestation for the expansion of agricultural farms and rangelands has driven to increasing soil losses and the growth of rock outcrops, soil nutrient depletion, decreasing productivity and macro environmental degradation in Ethiopia.

To combat these problem, Ethiopian government promotes soil and water conservation practices through community mobilization to increase production and productivity of the land, food security, improve livelihood of the community and mitigate environmental degradation $[8,9]$. Hence, since, 2010 different physical and biological soil and water conservation practices implemented by community campaign on privately owned and communal lands $[10,11]$. These physical and biological soil and water conservation practices implemented in a coordinated effort by the government with local community members [12]. Nevertheless, mass mobilization approaches lead to the implementation of soil and water conservation practices with inappropriate design and resulting the implemented practices had lesser impact on conserving soil and water than expected and consequently gully formation in many part of the country. These are due to technical gap and lack of skilled manpower in the community. Technical gap caused failure of implemented physical and biological soil and water conservation practices which in turn serious soil erosion and land degradation in the country and also in the study area, failure of implemented soil and water conservation practices was a serious problem like other part of the country due to improper design.

Thus, the purpose of this study was to evaluate the technical standard of implemented soil bund by community campaign in Adama, Lume and Dodota districts, CRV of Ethiopia. Subsequently, the result of the study could be helpful for soil and water conservation researchers and other academicians.

The objectives of this study were:-

- To evaluate the technical standard of implemented soil bund in the study area.

- To assess farmers' perception on soil erosion and conservation practices.

- To assess and describe major challenges farmers faced during soil and water conservation practices implementation.

\section{Methodology}

\subsection{Study Area Description}

The study was conducted in three selected districts of CRV of Ethiopia namely Lume, Adama and Dodota districts.

Lume district is found in the East Shewa Zone of Oromia Region and its located $70 \mathrm{Km}$ to the East of Addis Ababa the capital city of Ethiopia. The district is geographically located between $8^{0} 24^{\prime}-8^{\circ} 51^{\prime} \mathrm{N}$ latitude and $39^{\circ} 1^{\prime}-$ $39^{\circ} 17^{\prime} \mathrm{E}$ longitudes [13]. The total land area of the district is 75,220ha, which comprises a total of 35 Peasant associations. Lume is bordered in the South with Bora district, in the East Adama district, in the North Amhara region, in the West Ada'a Chukala district and in North-west with Gimbichu district. The administrative center of the district is Modjo town.

Adama district is bordered on the south by the Arsi Zone, on the southwest by Koka Reservoir which separates it from Bora district, on the west by Lume, on the north by the Afar region and on the east by Boset district. The altitude of the district ranges from 1500-2300m.a.s.l. The major soil type of the district is Andosol and about $74.3 \%$ of the district coved by this soil type. The remaining $25.7 \%$ of the districts' soil is Cambisols and Luvisols. Adama district has an estimated total population of 180,710 of which 91,859 are men and 88,851 are women [14]. The population density of the district is 207.4 people per square kilometer, which is greater than the zone average of 189.6 and the average farmland size per household was 2.5ha.

Dodota district is a part of Arsi zone and bordered on the south by Tena, on the southwest by Hitosa, on the north by the east shewa zone, on the east by Jelu and on the south east by sude district. The administrative center of the district is Dera and other towns include Awash Melkassa. The altitude of Dodota ranges from 1400 to 2500 m.a.s.l. The total land of the district shows that $23.2 \%$ cultivable, $10.6 \%$ pasture, $4.3 \%$ forest and the remaining $42 \%$ is considered swampy, mountainous or otherwise unusable. 


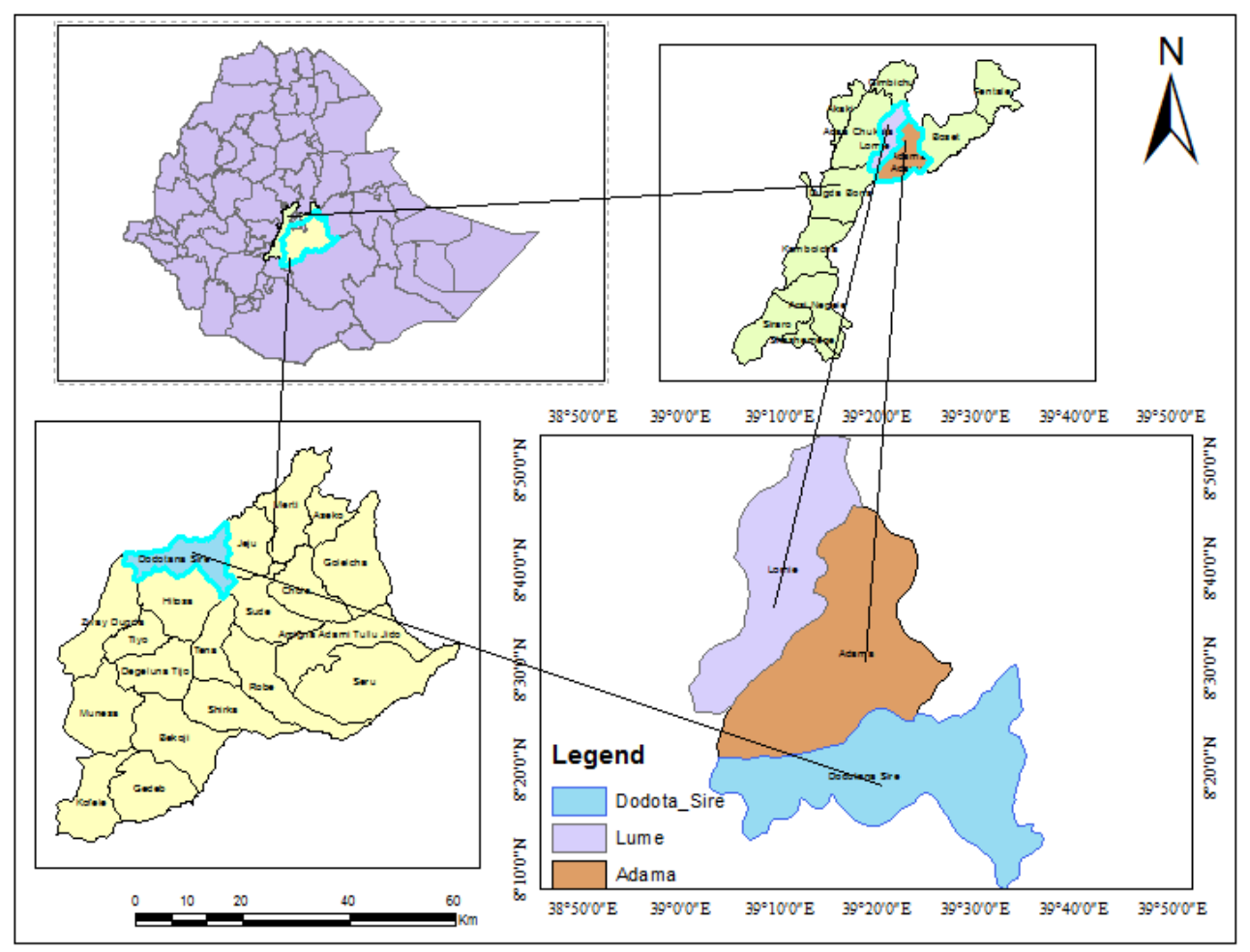

Figure-1. Map of the study area.

\subsection{Sampling Procedure}

Multistage sampling technique was employed to select the population for the study which involved purposive and random sampling techniques. First, districts were purposively picked, and secondly, kebeles were selected using lottery method. Finally, households were randomly chosen from the sampling frame (list of farmers) exist at kebele level. A total of 150 households were selected for this study.

\subsection{Data collection and Analysis}

Data was collected through structured questionnaire administered to sampled farmers by trained enumerators. Before the actual survey, the questionnaire was pretested in non-sampled villages. The pretest was not only used to test the appropriateness of the tool in collecting the required data but also to evaluate the trained enumerators on the capability of administering the questionnaire. In addition to these, soil bund structure implemented in the study area were measured and evaluated.

Information related to perception of farmers on soil and water conservation technologies, farmer's preferences of SWC practices and major challenges farmers faced by before and during soil and water conservation implementation were gathered from the respondents. Households' socio demographic, institution and economic features were also collected. Data were cleaned, organized and analyzed using SPSS software. Both descriptive and inferential statistics were used to analyze the gathered and cleaned data.

\section{Results and Discussions}

\subsection{Respondents' Socio Demographic Structures}

The study was conducted in three districts of CRV of Ethiopia. The total numbers of respondents interviewed were 150 and of which $84 \%$ respondents are male, the rest $16 \%$ were female respondents. The age of respondents showed that, $93 \%$ of respondents included the age of $18-64$ and the remaining $7 \%$ are $>64$ age Table 1 .

Out of the total respondents, education levels of $50.7 \%$ of the respondents were elementary school and $16.7 \%$ are uneducated. Concomitantly, $17.3 \%$ of respondents existed in high school education level. In this study, Adama $(16 \%)$ and Dodota $(12 \%)$ districts have the least illiterate respondents, and Lume have the highest uneducated $(22 \%)$ respondents.

The high number of family size was recorded under Dodota district than Adama and Lume which is smaller than the national average family size of 6.4 people per household. Hence, from this result and personal observation during field work it is possible to conclude and suggest that labor availability is key factor influencing households' decision to participate in soil and water conservation practices.

Table-1. Socio-demographic characteristics by districts.

\begin{tabular}{|c|c|c|c|c|c|}
\hline Variables & & $\begin{array}{c}\text { Lume } \\
(\mathrm{N}=\mathbf{5 0})\end{array}$ & $\begin{array}{l}\text { Adama } \\
(\mathrm{N}=50)\end{array}$ & $\begin{array}{l}\text { Dodota } \\
(\mathrm{N}=50)\end{array}$ & $\begin{array}{c}\text { Pooled } \\
(\mathrm{N}=150)\end{array}$ \\
\hline \multirow[t]{2}{*}{ Gender in \% } & Male & 84.0 & 90.0 & 78.0 & 84.0 \\
\hline & Female & 16.0 & 10.0 & 22.0 & 16.0 \\
\hline \multirow[t]{2}{*}{ Household head age in \% } & $18-64$ & 92.0 & 96.0 & 92.0 & 93.0 \\
\hline & $>64$ & 8.0 & 4.0 & 8.0 & 7.0 \\
\hline \multirow{5}{*}{ Household head education level in \% } & Non educated & 22.0 & 16.0 & 12.0 & 16.7 \\
\hline & Read and Write & 14.0 & 18.0 & 8.0 & 13.3 \\
\hline & Elementary school & 52.0 & 44.0 & 56.0 & 50.7 \\
\hline & High school & 12.0 & 20.0 & 20.0 & 17.3 \\
\hline & Diploma & 0.0 & 2.0 & 4.0 & 2.1 \\
\hline Family size & & 5.6 & 5.2 & 6.3 & 5.7 \\
\hline
\end{tabular}




\subsection{Standard of Implemented Soil Bund in the Study Area}

To evaluate the quality of implemented soil bund in the study area, parallel transect walk method was used to measure the dimensions of the implemented soil bund structures. The major physical soil and water structures were found in the study area, soil bund, waterway, cutoff drain, check dams and others. These structures have mainly constructed by community mobilization. Bund spacing, bund gradient, field slopes, bund cross sectional areas like embankment height, top and bottom width and channel depth and width were measured and evaluated.

Accordingly, the implemented soil bund structures were above and below the standards. Soil bund parameters implemented below the specified standards were bund spacing, bund depth, and height of embankment and bottom width of embankment. While, bund top width, bund bottom width, berm width and top width of embankment are better Table 2. During field observation, there was no any similarity between the existing soil bund structures in the area. The main reasons for soil bund implemented below the standards are knowledge and skill gap on soil and water conservation structures. This was not only farmers but also development agents have knowledge and skill gap on designing the structures. In the study area, usually communities perceived that implementing soil bunds in narrow spacing may create difficulty in plowing activities and reduces farm size at the same time needs much labor forces to implement. Traditionally, farmers were using traditional drainage ditches on their farmlands to disposed excess runoff during high rainfall. Nonetheless, this type of conservation measure was out of the standard which had negative impact on soil erosion control since the drainage ditches have on average high slope gradient which leads to erosion along traditional drainage ditches and create excess siltation on the lower part. Similar finding by Gizaw [15] reported that, farmers construct drainage ditches every year and sediments eroded from the ditches and accumulated down slope were common indicators of erosion on farmer's farmlands.

Table-2. Comparison between standards and implemented soil bund structure.

\begin{tabular}{l|c|c|c|c}
\hline Parameters & National standards & Lume & Adama & Dodota \\
\hline Slope for the sites $(\%)$ & $>3$ & 4.3 & 4.3 & 4.3 \\
\hline Slope of the level bund $(\%)$ & 0 & 0.2 & 0.1 & 0.1 \\
\hline Bund length $(\mathrm{m})$ & $30-80$ & 55.8 & 57.4 & 60.2 \\
\hline Bund spacing $(\mathrm{m})$ & 34.9 & 10.7 & 22.8 & 21.5 \\
\hline Bund depth $(\mathrm{cm})$ & 50 & 30 & 40 & 37 \\
\hline Bund top width (cm) & 50 & 72.9 & 77.5 & 76.3 \\
\hline Bund bottom width $(\mathrm{cm})$ & 50 & 70.3 & 60.2 & 72.6 \\
\hline Berm width $(\mathrm{cm})$ & 5 & 20 & 12.5 & 11.1 \\
\hline Height of embankment $(\mathrm{cm})$ & 60 & 28.3 & 44.2 & 45 \\
\hline Top width of embankment $(\mathrm{cm})$ & 30 & 43.3 & 36.7 & 35.2 \\
\hline Bottom width of embankment $(\mathrm{m})$ & 1.1 & 1 & 1 & 1 \\
\hline
\end{tabular}

\subsection{Farmers' Perception on Soil Erosion}

Finding of the survey revealed that, $82.8 \%$ of Lume districts', $78.3 \%$ of Adama district and $77.6 \%$ of Dodota districts' respondents were implemented soil and water conservation practices to reduce the risk of soil erosion. While $17.2 \%$ of Lume district, $21.7 \%$ of Adama district and $22.4 \%$ of Dodota district respondents were not implemented any of the soil and water conservation structures to control soil erosion in the study area Table 3.

Table-3. Farmers SWC structures implementers and non-implementer.

\begin{tabular}{l|l|l|l}
\hline SWC implementers & Lume & Adama & Dodota \\
\hline SWC implementers in \% & 82.8 & 78.3 & 77.6 \\
\hline SWC non implementer in \% & 17.2 & 21.7 & 22.4 \\
\hline
\end{tabular}

Farmers had different interest in soil and water conservation practices. Majority of farmers showed high interest to conserve their soil while limited number of farmers were reluctant. Most of the time farmers whose lands were seriously degraded by erosion were highly interested to conserve the soil. These farmers were those residing in the upper part of the watershed. In contrary, farmers those lands were less degraded by soil erosion showed less interest. In terms of soil and water conservation structures users, $77.4 \%, 69.5 \%$ and $68.9 \%$ of respondents perceived the degree of soil erosion as sever from Lume, Adama and Dodota districts, respectively. In case of non-user groups (non-conservation implementers), majority of the respondents perceived the degree of soil erosion was moderate to minor on their croplands Table 4. The result of chi-square test showed that, respondents' perception on the degree of soil erosion on their farmlands were significantly different between conservation practices implementers and non- implementers. The reason is that, due to different in respondents' education level and the degree of soil erosion problem on their cultivated lands. FGD and key informant interviewer also responded that the main causes of soil erosion in the study area were easily erodible nature of soils, uncontrolled grazing, inappropriate farming system, deforestation and poor watershed management. This result is in line with the finding of Kibemo [16] who stated that, educated farmers have better understanding the existence of soil erosion than uneducated farmers.

Table-4. Farmers' perception on soil erosion in the study area.

\begin{tabular}{|c|c|c|c|c|c|c|c|}
\hline \multirow[b]{3}{*}{ Degree of erosion } & \multicolumn{6}{|c|}{ Districts } & \multirow[b]{3}{*}{$\chi^{2}$} \\
\hline & \multicolumn{2}{|c|}{ Lume } & \multicolumn{2}{|c|}{ Adama } & \multicolumn{2}{|c|}{ Dodota } & \\
\hline & $\begin{array}{c}\text { SWC } \\
\text { user (\%) }\end{array}$ & $\begin{array}{c}\text { Non- } \\
\text { user (\%) }\end{array}$ & $\begin{array}{c}\text { SWC user } \\
(\%)\end{array}$ & $\begin{array}{c}\text { Non-user } \\
(\%)\end{array}$ & SWC user (\%) & $\begin{array}{c}\text { Non-user } \\
(\%)\end{array}$ & \\
\hline Sever & 77.4 & 1.7 & 69.5 & 8.8 & 68.9 & 5.3 & $0.067 \mathrm{NS}$ \\
\hline Moderate & 12.3 & 1.5 & 7.5 & 6.4 & 15 & 4.7 & $0.078 \mathrm{NS}$ \\
\hline Minor & 6.4 & 0.7 & 3.5 & 4.3 & 3 & 3.1 & $0.032 \mathrm{NS}$ \\
\hline Total & 96.1 & 3.9 & 80.5 & 19.5 & 86.9 & 13.1 & \\
\hline
\end{tabular}




\subsection{Farmers' Preferences of Soil and Water Conservation Practices}

Preferences about soil and water conservation technologies strongly affects farmers' adoption decision. In the study area, most of the time farmers prefer soil bund (95\%) and stone bund (80\%) to implement on their own lands Table 5. As indicated in the focus group discussion, check dam and gully rehabilitation technologies were less prefered by respondents' since these conservation practices needs skilled manpower and intensive labor. Moreover, farmers have limited information about the values of these physical and biological conservation practices and destruction of biological materials by free grazing in the area. During field observation, it was witnessed that the nature of livestock husbandary was open grazing style this created damaging of structures by animal trampling over the structures. This makes that the concentration of runoff forms more erosion han inconserved areas. The chi-square test revealed that, there is insignificant difference among respondents' perception on the effectivness of physical soil and water conservation practices. Majority of respondents perceived soil and stone bund were effective to control soil erosion while some proportions perceived check dam maked them more effective to control erosion. This is may happned, due to the difference in degree of erosion among respondents' land, severity and minor eroded soils, farmers implement different structures to control runoff and sediment movement.

Table-5. Farmers' preferences of soil and water conservation practices.

\begin{tabular}{c|c|c}
\hline Types of structure & Farmers' preference in \% & Rank \\
\hline Soil bund & 95 & 1 \\
\hline Stone bund & 80 & 3 \\
\hline Waterway & 78 & 4 \\
\hline Cut off drain & 77 & 5 \\
\hline Gully rehabilitation & 63 & 6 \\
\hline Check dam & 58 & 7 \\
\hline
\end{tabular}

Regarding structure maintainance, only $23 \%, 12.5 \%$ and $9.8 \%$ respondents from Lume, Adama and Dodota districts, respectively have maintained the structures on their farmlands Table 6. The absence of structural maintainance are due to farmers perception on consquences of erosion education, land ownership and family size or labor availability were major determinant farctors listed by farmers to not maintain the implemented structures individually. In most cases, farmers were not voluntary to maintain the implemented structures since hetrogeneity of the problem over landscape, variability in the size of land holding per househld and difference in perception to soil erosion.

Table-6. Structures maintained by districts in the study area.

\begin{tabular}{c|c}
\hline Districts & Structures maintained \\
\hline Lume & $23.1 \%$ \\
\hline Adama & $12.5 \%$ \\
\hline Dodota & $9.8 \%$ \\
\hline
\end{tabular}

\subsection{Farmers Provided Extension Services and Training on Soil and Water Conservation Practices}

\subsubsection{Access to Extension Services}

According to the household survey, $69 \%$ of Lume, $72 \%$ of Adama and $66 \%$ of Dodota respondents got better extension service on soil and water conservation technologies in the study area Figure 2. The chi-square test confirmed that there is no significant difference between districts with regard to extension services $(\mathrm{P}>0.05)$. As indicated in the focus group discussion, frequent contact of extension worker is also related to the socio-economic status of the farmers. Frequently, extension workers might prefer to visit farmers with more farmland or those who have already adopted the soil and water conservation technologies in the area.

The importance of extension service is to initiate change that bring about sound soil and water conservation especially on the part of smallholder farmers as it offers them technical advice on necessary services. Therefore, extension service is fundamental for the natural resource conservation, providing training, technical advice, accessing the supply of inputs timely and giving various information that ranges from production to marketing. Moreover, it represent local farmers' frequency of contact with DAs and frequency of participation in extension planning, training, field day, on-farm trial and demonstration regarding land management, agriculture and livestock production. Thus, extension service has positive impact on enhancing soil and water conservation technologies.

\subsubsection{Access to Training}

Training on soil and water conservation technologies is one of the key factor than influence the participation of farmers in soil and water conservation practices. Accordingly, 37\% of Lume, 39\% of Adama and 29\% of Dodota districts' respondents have access to training on SWC technologies Figure 3. The statistical test result confirmed that there was a negative and significant relationship between districts with regard to participation in soil and water conservation training $(\mathrm{P}<0.05)$ with Dodota having low participation. This indicated that the number of farmers got training were better at Lume and Adama districts. Hence, during focus group discussants responded that most of the time training was given by different NGOs like MERET and SLM (sustainable land management) in Lume and Adama districts. On the other hand, in Dodota district, farmers got training access often from government bodies including political leaders. The more the local farmers get soil and water conservation training, the more likely that they acquire the relevant information along with the technical; known the importance of soil and water conservation technologies. Training creates awareness and helps the local farmers to perform bring innovation and invention in soil and water conservation technologies. Hence, training as the fundamental element to change the perception of local farmers in order to adopt and expand soil and water conservation technologies. 


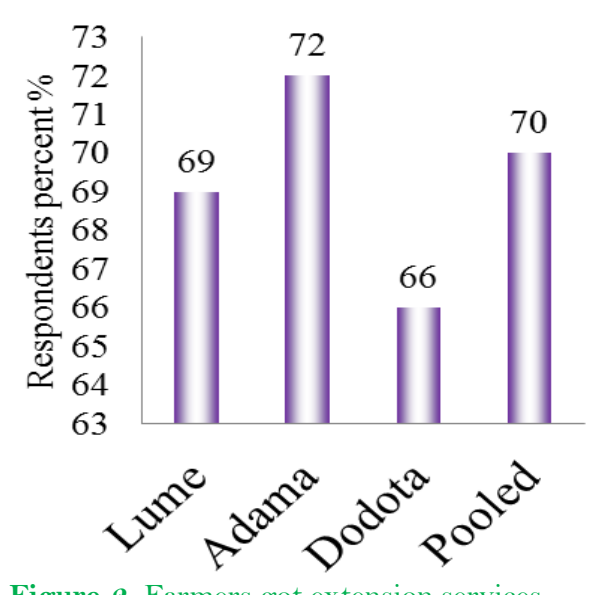

Figure-2. Farmers got extension services.

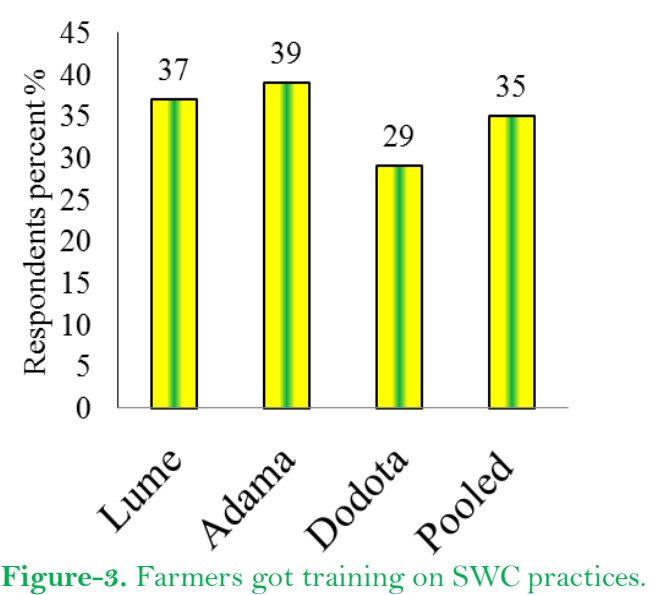

Figure-3. Farmers got training on SWC practices.

\subsection{Major Challenges Farmers' Faced During Soil and Water Conservation Structures Implementation}

Main challenges such as lack of labor, lack of technical skills, lack of farm tools, fear of animal trampling and lack of awareness are the major challenges in the study area though farmers appear to face such problems Figure 4. In the study area, usually soil and water conservation practices carried out in the dry season when no or little labor is needed for agricultural activities. Because, labor for the establishment constitutes the largest part of the investments in soil and water conservation practices. The technological options are less available in the study area to relieve humans. Thus, farm execution of most farm related works require human labor, among other. Physical soil and water conservation structures implementation and maintenance require intensive labor for which machinery has not been introduced or developed in the country.

The durability of SWC structures mainly based on the slope of the area, rainfall intensity, soil stability and land use type and management, but it needs frequent maintenance such as de-silting and repairing broken parts. A guideline by the Ethiopian ministry of agriculture estimates 150-250PD for the construction of the kilometer of commonly practices soil and water conservation structures, such as soil bunds, fanyajuu, stone bunds [17]. In this case, labor may remain a challenge for the undertaking human labor based soil and water conservation activities in the area.

Regarding lack of farm tools, challenge raised by farmers was no provision of spades and dig to excavate the soil and fear of animal trampling in the area, since structures implemented less quality and ineffective in the area. That is also what is explained by Kebede [10] which indicated that labor demand appears much more than the requirement for most ordinary farming business.

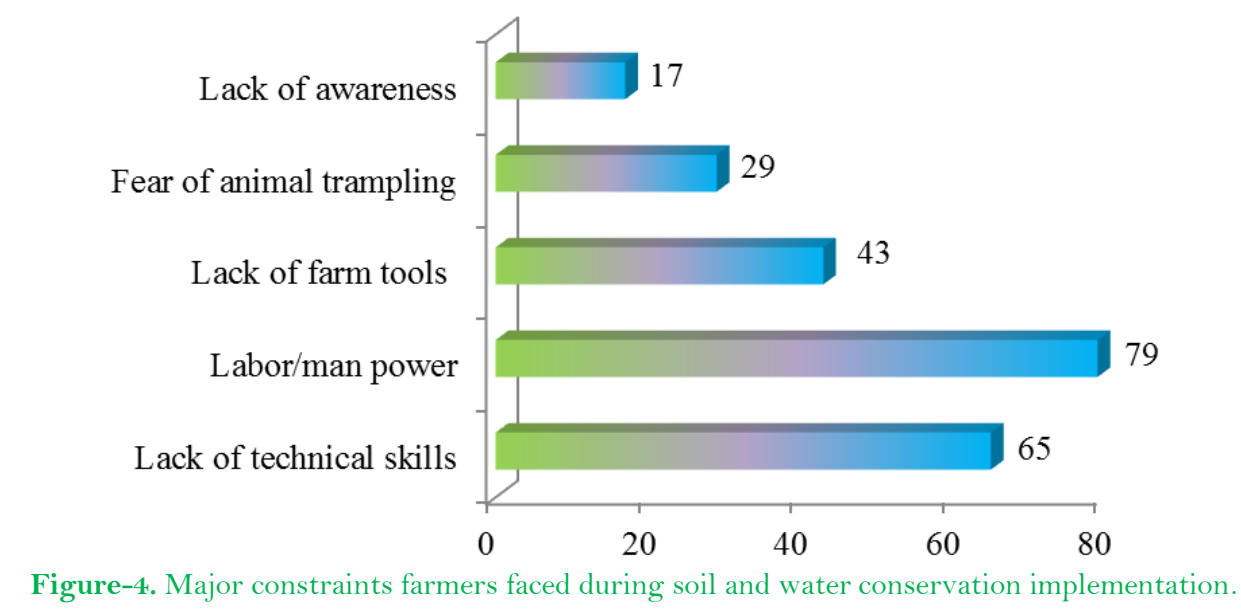

\section{Conclusion and Recommendations}

The participation of women are better at Dodota district than Lume and Adama (mean=16\%). Regarding family size, the high number of family size recorded under Dodota district compared to Lume and Adama. Soil bund parameters implemented below the standard are bund spacing, bund depth and height of embankment. Whereas, bund top width, bund bottom width, berm width and top width of embankment are better. Due to this, runoff generated over tops causing rill and gully formation which is difficult to control.

With regard to SWC technology preferences; soil and stone bund are mostly preferred while, check dam is the least preferred technology to implement in the study area. The study result shown that, SWC implementers challenged by constraints like shortage of labor, lack of technical skills, fear for animal trampling, lack of awareness and lack of sufficient farm tools. To sum up, every year SWC practices implemented by community mobilization are not standardized and thus it is difficult to manage the watershed in different areas.

Therefore, based on the above findings the following recommendations can be drawn for further consideration and improvement of soil and water conservation practices in the study area in particular and in the country in general.

- Well organized training should be given for experts at different levels to fill the technical gap on their skills.

- Extension services like demonstration should be held for all stakeholders before implementing the soil and water conservation structures.

- Soil and water conservation structures should be planned by experts at Kebeles and district levels rather than planning at zonal or regional levels for its quality and effectiveness. 


\section{References}

[1] T. Genene and G. Abby, "Review on overall status of soil and water conservation system and its constraints in different agro ecology of southern Ethiopia," Journal of Natural Sciences Research, vol. 4, pp. 59-69, 2014.

[2] H. Hurni, "Land degradation, famine, and land resource scenarios in Ethiopia. In: Pimentel D, editor. World Soil Erosion and Conservation," ed Cambridge, UK: Cambridge University Press, 1993, pp. 27-61.

[3] T. Girma, "Land degradation: A challenge to Ethiopia," Environmental Management, vol. 27, pp. 815-824, 2001. Available at: https://doi.org/10.1007/s002670010190.

[4] D. Nigatu, F. Kalkidan, and M. Tewodros, "Soil and water conservation practices on crop productivity and its economic implications in Ethiopia: A review," Asian Journal of Agricultural Resource, vol. 11, pp. 128-136, 2017. Available at: https://doi.org/10.3923/ajar.2017.128.136.

[5] N. Haregeweyn, J. Poesen, J. Nyssen, G. Verstraeten, J. De Vente, G. Govers, S. Deckers, and J. Moeyersons, "Specific sediment yield in Tigray-Northern Ethiopia: Assessment and semi-quantitative modelling," Geomorphology, vol. 69, pp. 315-331, 2005. Available at: https://doi.org/10.1016/j.geomorph.2005.02.001.

[6] M. D. Tsegaye, A. Tsunekawa, M. Tsubo, and N. Haregeweyn, "Dynamics and hotspots of soil erosion and management scenarios of the Central Rift Valley of Ethiopia," International Journal of Sediment Research, vol. 27, pp. 84-99, 2012. Available at: https://doi.org/10.1016/j.geomorph.2005.02.001

[7] K. T. Belay, A. Van Rompaey, J. Poesen, B. S. Van, J. Deckers, and K. Amare, "Spatial analysis of land cover changes in eastern Tigray (Ethiopia) from 1965 to 2007: Are there signs of a forest transition?," Journal of Land Degradation Development, vol. 26, pp. 680-689, 2015. Available at: https://doi.org/10.1002/ldr.2275.

[8] N. Haregeweyn, A. Tsunekawa, J. Nyssen, J. Poesen, M. Tsubo, D. T. Meshesha, B. Schütt, E. Adgo, and F. Tegegne, "Soil erosion and conservation in Ethiopia: A review," Journal of physical geography, vol. 39, pp. 750-774, 2015.

[9] B. Gessesse, W. Bewket, and A. Bräuning, "Determinants of farmers' tree-planting investment decisions as a degraded landscape management strategy in the central highlands of Ethiopia," Solid Earth, vol. 7, pp. 639-650, 2016. Available at: https://doi.org/10.5194/se-7-639-2016.

[10] W. Kebede, "Effect of soil and water conservation measures and challenges for its adoption: Ethiopia in focus," Journal of Environmental science and Technology, vol. 7, pp. 185-199, 2014.

[11] A. Teshome, J. de Graaff, C. Ritsema, and M. Kassie, "Farmers' perceptions about the influence of land quality, land fragmentation and tenure systems on sustainable land management in the north western Ethiopian highlands," Land Degradation $\mathcal{E}^{\circ}$ Development, vol. 27, pp. 884-898, 2016. Available at: https://doi.org/10.1002/ldr.2298.

[12] T. Amare, A. D. Zegeye, B. Yitaferu, T. S. Steenhuis, H. Hurni, and G. Zeleke, "Combined effect of soil bund with biological soil and water conservation measures in the northwestern Ethiopian highlands," Ecohydrology \& Hydrobiology, vol. 14, pp. 192-199, 2014. Available at: https://doi.org/10.1016/j.ecohyd.2014.07.002.

[13] A. Kebede and J. Kideghesho, "Community-based land use Planning for conservation and development," InWEnt-GTZ Training Course. Ethiopia, 2004.

[14] CSA, Population and housing census report. Administrative report, Addis Ababa, 2007.

[15] D. Gizaw, "Conceptualizing rill erosion as a tool for planning and evaluating soil conservation in Angereb watershed," Ethiopia: Methodological Development Research Report for Q505 Project Supported by Eastern and Southern Africa Partnership Program (ESAPP). Retrieved from: https://doi.org/10.7892/boris.692862010.

[16] D. Kibemo, "Farmers' perception on soil erosion and their use of structural soil conservation measures in Soro District, Southern Ethiopia," MSc Thesis, Addis Ababa University, Ethiopia, 2011.

[17] D. Lakew, V. Carucci, W. Asrat, and A. Yitayew, "Community based participatory watershed development: A guideline, part 1, ministry of agriculture and rural development, federal democratic republic of ethiopia ministry of agriculture and rural development, Addis Ababa, Ethiopia, January 2005," 2005. 